\title{
El requisito de la especial trascendencia constitucional: «decidir no decidir»
}

\author{
Yessica Esquivel Alonso ${ }^{1}$ \\ Becaria del Tribunal Constitucional (2011-2012)
}

\begin{abstract}
Sumario: 1. Introducción.-2. El amparo y la reforma de la Ley Orgánica 6/2007, de 24 de mayo. 2.1. La exigibilidad de la especial trascendencia constitucional en el recurso. 2.2. La imposición al demandante de justificar la relevancia constitucional. 2.2.1. Verificación del juicio de admisión a trámite. 2.2.2. Resolución de inadmisión.-3. El concepto de especial trascendencia constitucional.-4. Evolución en la doctrina del Tribunal Constitucional. 4.1. Ausencia de doctrina constitucional. 4.2. Aclaración de doctrina. 4.3. Vulneración de derechos fundamentales en la ley. 4.4. Vulneración del derecho fundamental en la aplicación de la ley. 4.5. Incumplimiento jurisdiccional reiterado de la doctrina constitucional. 4.6. Negativa judicial de acatamiento de la doctrina constitucional. 4.7. Repercusión social, económica o política-5. Algunas consideraciones finales.
\end{abstract}

\section{INTRODUCCIÓN}

En los años noventa se detectó un incremento desmesurado del número de amparos que llegaban al Tribunal Constitucional. El aumento fue tan desmedido que rápidamente se convirtió en un problema que amenazó con entorpecer la función jurisdiccional. La solución exigía que se estableciera un «remedio legal» que permitiera al juez constitucional seleccionar los casos más relevantes con la finalidad de aligerar la sobrecarga de recursos y evitar colapsar el acceso a la justicia constitucional. De tal suerte que se pensó en admitir únicamente aquellos recursos de amparo que acreditaran un objetivo interés constitucional. Para llevar a cabo este y otros propósitos, se reformó la Ley Orgánica del Tribunal Constitucional (en adelante LOTC).

Con la reforma 6/2007, de 24 de mayo, el amparo constitucional se trasformó en un recurso selectivo y ambiguo. Aunque a nuestro juicio, el cambio más contundente fue el que convirtió al recurso de amparo subjetivo en objetivo, lo que implicó se excluyera el presupuesto procesal que lo caracterizaba: la efectiva tutela de los derechos y libertades fundamentales (art. $53 \mathrm{CE}$ ).

${ }^{1}$ Becaria del Tribunal Constitucional de 2011 a 2012.

Doctoranda en Derecho del Instituto de Derecho Parlamentario de la Universidad Complutense de Madrid. Agradezco al Profesor Ignacio Torres Muro, José Antonio Estrada Marún y Jorge Páez Mañá las observaciones hechas a este artículo. Cualquier error que se detecte será de mi exclusiva responsabilidad. 
La reforma también modificó, entre otros aspectos, el trámite de admisión del recurso de amparo, imponiendo al recurrente la carga de justificar la relevancia constitucional del asunto alegado. Este requisito fue denominado «especial trascendencia constitucional» concebido como presupuesto de base legal cuyo contenido se ha ido determinado jurisprudencialmente.

El nuevo requisito desde su nacimiento causó confusión entre los operadores jurídicos. No fue hasta el 2009, dos años después de la reforma, cuando por primera vez se establecieron los presupuestos para la acreditación de la especial trascendencia constitucional en la STC 155/2009, de 25 de junio, FJ $2^{\circ}$. En la práctica dichos criterios permiten un extenso margen de apreciación del juez constitucional en el encuadre del supuesto previsto, situación que produce dos efectos simultáneos: por un lado, se reafirma el campo de libertad del que dispone el juez constitucional para analizar el caso concreto y proyectar sus apreciaciones; y por el otro, dicha discrecionalidad puede acarrear incertidumbre jurídica entre los aplicadores del derecho. En efecto, son pocas las sentencias que especifican con claridad qué presupuesto se tiene por acreditado y en qué términos ha sido satisfecho. Por tal motivo, el presente trabajo se ha dado a la tarea de identificar las sentencias o autos del Tribunal Constitucional que hacen alguna aportación a la delimitación del requisito de la especial trascendencia constitucional, con el objetivo de reflexionar sobre su evolución en la doctrina constitucional española.

\section{EL AMPARO Y LA REFORMA DE LA LEY ORGÁNICA 6/2007, DE 24 DE MAYO}

El recurso de amparo constituía en el sistema de justicia constitucional español el instrumento procesal final del sistema de garantías de los derechos y libertades fundamentales (arts. 14 al $29 \mathrm{CE}$ ). El Tribunal Constitucional fue durante mucho tiempo la última instancia que conocía sobre la tutela de los derechos fundamentales.

El inmoderado incremento del amparo constitucional generó excesivas dilaciones en las resoluciones, provocando que fuera casi imposible obtener un pronunciamiento en tiempo ${ }^{2}$. Es decir, se comenzaron a dictar sentencias con considerable retraso, quedando sin materia algunos recursos por no representar un problema constitucional al momento de resolverse, impidiendo se cumpliera con el objetivo del amparo: la efectiva protección de los derechos fundamentales ${ }^{3}$.

${ }^{2}$ Borrajo Iniesta, I., «Mitos y realidades de la jurisdicción constitucional de amparo: hechos, derecho, pronunciamientos, admisión, costes», Teoría \& Derecho. Revista de pensamiento jurídico, núm. 3, 2008, p. 39. El autor señala dos posibles causas del incremento desmesurado del amparo: a) la insuficiencia de la gratuidad del amparo y b) los efectos perversos del sistema de honorarios actual.

${ }^{3}$ Por ejemplo: la STC 128/1999, de 1 de julio, FJ $14^{\circ}$, que conoce de un decreto del año 1991 sobre materia agraria en aplicación de la acción común de la Unión Europea 
El desbordamiento ${ }^{4}$ del amparo constitucional se tornó rápidamente en una inminente amenaza para el Tribunal Constitucional ${ }^{5}$. La realidad obligó incluso a los que se resistían a abandonar el recurso adoptado hasta entonces, a la búsqueda de un modelo asequible que asegurará la eficiencia y la efectividad del recurso ${ }^{6}$.

Las propuestas para la mejora del amparo fueron muchas y variadas, algunas estructurales y otras procedimentales 7 . Por ejemplo: se pensó en reinterpretar el recurso de amparo como una garantía excepcional de protección de derechos fundamentales y no como una última instancia jurisdiccional ${ }^{8}$. Existieron voces que se decantaron por desaparecer la tutela del art. $24 \mathrm{CE}$ para descargar la jurisdicción constitucional y encauzarla exclusivamente en la vía ordinaria ${ }^{9}$. Se contempló crear más Salas al interior del Tribunal Constitucional. Se propuso incrementar el cuerpo de letrados; incluso se especuló como solución más radical eliminar el amparo, conminando a una especie de sensatez europea

que, al momento de enjuiciarse, había sido modificado en más de una ocasión por diversas normativas posteriores.

${ }^{4}$ De acuerdo con las memorias del Tribunal Constitucional, en el año 2006 ingresaron al Tribunal 11,741 asuntos de los cuales 11,471 fueron amparos. En el año 2007 ingresaron 10,013 asuntos, de éstos 9,840 fueron amparos. En 2008 ingresaron 10,410 asuntos de los que 10,279 fueron amparos. Durante el 2009 ingresaron 10,848 asuntos de éstos 10,792 fueron amparos. En 2010 ingresaron 9,041 asuntos de los cuales 8,947 fueron amparos. En 2011 ingresaron 7,192 asuntos, de éstos 7,098 fueron amparos. En 2012 ingresaron 7,294 nuevos asuntos, de éstos 7,205 fueron amparos. Información consultada el 22 de agosto del 2013 en www.tribunalconstitucional.es/es/tribunal/memorias/Paginas/default.aspx

${ }^{5}$ Como se desprende de la Exposición de Motivos de la reforma LO 6/2007, de 24 de mayo, por la que se modifica la Ley Orgánica 2/1979, de 3 de octubre, del Tribunal Constitucional, Boletín Oficial del Estado, de 25 de mayo de 2007, núm. 125: «hasta el punto de ocupar casi la totalidad del tiempo y los medios materiales y personales del Tribunal» y contribuir a la «lentitud de los procedimientos».

${ }^{6}$ Pérez Tremps, P., El recurso de amparo, Tirant lo Blanch, Valencia, 2004, p. 24. A juicio del autor es una acción procesal, extraordinaria, subsidiaria, flexible y definitiva.

${ }^{7}$ Véase Aragón Reyes, M., «Cuestionario sobre la Reforma de la Ley Orgánica del Tribunal Constitucional», Teoría y Realidad Constitucional, núm. 4, 1999, p. 19; «Encuesta sobre la reforma de la Ley Orgánica del Tribunal Constitucional», Teoría y Realidad Constitucional, núm. 18, pp. 11-73; y «Respuestas a la encuesta» en VV.AA., La reforma de la justicia constitucional, Thomson Aranzadi, Centro de Estudios Jurídicos, Navarra, pp. 81-147, entre otros.

8 Véase la STC 76/2007, de 16 de abril, FJ $2^{\circ}$, donde se establece expresamente «la exigencia de agotar todos los recursos utilizables en vía judicial ordinaria como consecuencia del carácter subsidiario del recurso de amparo, ya que la tutela general de los derechos y libertades corresponde primeramente a los órganos del Poder Judicial, y, por tanto, cuando existe un recurso susceptible de ser utilizado, y adecuado por su carácter y naturaleza para tutelar la libertad o derecho que se entiende vulnerado, tal recurso ha de agotarse antes de venir a este Tribunal». En el mismo sentido, la STC 103/2004, de 2 de junio, FJ $2^{\circ}$, entre otras.

9 Garberí Llobregat, J., «Artículo 48» y "Artículo 49», en Requejo Pagés, J.L. (Coord.), Comentarios a la Ley Orgánica del Tribunal Constitucional, Boletín Oficial del Estado, Madrid, 2001, pp. 783-795. 
como la de los franceses, italianos e ingleses, donde el recurso de amparo es inexistente ${ }^{10}$.

Tras múltiples deliberaciones parlamentarias, el legislador optó por modificar el trámite de admisión del recurso de amparo con la finalidad de agilizarlo y hacer los requisitos más rígidos. En suma, la reforma de la LOTC cambió el recurso de amparo. La esencia de la reforma, se puede analizar en dos vertientes principales: a) exigibilidad de la especial trascendencia constitucional en el recurso, b) la imposición al demandante de justificar la relevancia constitucional.

\subsection{La exigibilidad de la especial trascendencia constitucional en el re- curso}

El recurso de amparo nace con una precondición subjetiva que tiene como finalidad tutelar los derechos fundamentales. Pero, la reforma trajo consigo una visión objetiva del amparo que «pervirtió» su naturaleza jurídi$\mathrm{ca}^{11}$. El aspecto objetivo amplió el margen de apreciación de los jueces constitucionales permitiéndoles no pronunciarse sobre cuestiones especialmente sensibles como es la protección de los artículos 14 al $29 \mathrm{CE}^{12}$. Dicha facultad se materializa en condicionar la admisión del amparo a la acreditación de ciertos presupuestos, que a criterio del Tribunal Constitucional, tengan especial interés constitucional.

${ }^{10}$ Véase el comentario de PARADA dado con motivo del Cuestionario sobre la Reforma de la Ley Orgánica del Tribunal Constitucional en ArAgón ReYEs, M., «Cuestionario sobre la Reforma de la Ley Orgánica del Tribunal Constitucional», ob. cit., p. 64. PARADA, J.R enfatizó: « ¡Seamos, pues, realistas! Reconozcamos el fracaso y eliminemos el recurso de amparo, poniéndonos a la altura de la sensatez de franceses, italianos e ingleses, entre otros vecinos de nuestro mismo ámbito cultural y cuya felicidad jurídica no es menor sino mayor a la nuestra».

11 Oliva SAntos, D. A., «La perversión jurídica del Amparo Constitucional en España», Actualidad Jurídica Aranzadi, núm. 751, 2008, p. 18. «Hablar de perversión jurídica del amparo constitucional en España es simple y obligada consecuencia de la naturaleza del amparo conforme a la Norma Fundamental aun formalmente en vigor».

12 Garro Vargas, A., «El debate sobre la reforma del recurso de amparo en España: análisis de algunas de las propuestas a la luz de la Constitución», Revista Española de Derecho Constitucional, núm. 76, enero-abril 2006, p. 128. El autor adopta una postura en la que reafirma que la función insustituible del Tribunal Constitucional es la de supremo intérprete de la Constitución, no así la tutela subjetiva de los derechos fundamentales, postura visiblemente contraria a la que sostienen otros autores. Por ejemplo: Aragón ReYes, M., «Las dimensiones subjetiva y objetiva del nuevo recurso de amparo» en Otrosí, núm. 10, abril-junio 2012, pp. 11 y 12. Afirma que el amparo pasa de un amparo-tutela que tendría lugar siempre que hubiera existido vulneración de derechos a una amparo-control que únicamente se ejercerá por el Tribunal cuando en el caso se dé un supuesto «especial trascendencia constitucional» que se apreciará atendiendo a los siguientes criterios: su importancia para la interpretación de la Constitución, para su aplicación, su general eficacia, la determinación del contenido y alcance de los derechos fundamentales. 
Tanto el modelo estadounidense del certiorari $^{13}$ como en el modelo alemán ${ }^{14}$, con el juicio de relevancia constitucional, fueron fuentes de inspiración de la especial trascendencia constitucional. Ambas figuras jurídicas se crearon con el propósito de limitar drásticamente la admisión de los recursos a la competencia constitucional. Sin embargo, pareciera que el amparo constitucional español supera la dimensión objetiva de sus predecesores por las siguientes razones. En primer lugar, el recurso de amparo español es mucho más riguroso que el juicio de relevancia constitucional alemán porque permite la negación a trámite del recurso, aun y cuando el fondo pudiera lesionar gravemente algún derecho fundamental. En segundo lugar, también ha superado al certiorari, dado que el recurso de amparo español inadmite desde el trámite de admisión todas aquellos asuntos que no se ajusten a los criterios nominales previstos para actualizar la especial trascendencia constitucional, impidiendo que el juez constitucional se pueda pronunciar sobre la eventual relevancia constitucional del fondo del asunto.

Algunos autores como Requejo Pagés sostienen que el cánon de relevancia constitucional ha estado presente desde que se conoce la figura del recurso de amparo, afirmando que «el Tribunal siempre ha admitido lo que quiere, porque todo lo que el Tribunal inadmite por el $50.1 \mathrm{c}$ ) -carece manifiestamente de contenido- que no son más que desestimaciones anticipadas, de suerte que este artículo opera como la válvula que lo faculta a inadmitir lo que no interesa» ${ }^{15}$. De esta manera el autor corrobora la presencia del certiorari en la doctrina constitucional española y desmitifica la innovación aludida en la reforma.

En la misma línea argumentativa, Pérez Guerra reconoce la dimensión objetiva del recurso de amparo y la existencia de la especial trascendencia constitucional desde la configuración inicial del amparo. Adicionalmente la autora destaca que la reforma no ha eliminado la dimensión subjetiva de esta garantía, sino que busca «objetivamente» incrementarla siendo más exigente en el acceso al Tribunal Constitucional, haciendo posible de esta manera que

${ }^{13}$ Para mayor abundamiento véase Ahumada Ruiz, M. A., «El “certiorari”. El ejercicio discrecional de la jurisdicción de apelación por el Tribunal Supremo de los Estados Unidos», Revista Española de Derecho Constitucional, núm. 41, mayo-agosto 1994, pp. 89-136.

${ }^{14}$ Un estudio sobre el mismo, Rodríguez Álvarez, J. L. «Seleccionar lo importante. La reciente reforma del trámite de admisión de la "Verfassungsbeschwerde"》, Revista Española de Derecho Constitucional, núm. 41, mayo-agosto 1994, pp. 139-148; y HerNÁNDEZ RAmos. M., «El Tribunal Constitucional Federal Alemán aún en la encrucijada. Balance de medio siglo de reformas del trámite de admisión de la Verfassungsbeschwerde», Revista Española de Derecho Constitucional, núm. 88, enero-abril 2010, pp. 83-130.

15 Véase la participación de Requejo Pagés, J.L. en el trabajo de Fernández FarReRES, «La reforma de la Ley Orgánica del Tribunal Constitucional (Comentario a la Ley Orgánica 6/2007, de 24 de mayo)», Revista Española de Derecho Constitucional, núm. 81, septiembre-diciembre 2007, p. 22. 
sus sentencias sean efectivos instrumentos de protección de derechos fundamentales ${ }^{16}$.

La dimensión objetiva y subjetiva del amparo es un tema ampliamente debatido, al respecto concurren interesantes postulados que invitan a la reflexión, sin que hasta el momento exista un consenso ${ }^{17}$. A pesar del amplio debate teórico, el Tribunal Constitucional ha caminado en un sentido muy puntual: la objetivación del amparo, al afirmar que:

«La reforma llevada a cabo por la Ley Orgánica 6/2007 en la regulación del recurso de amparo ha eliminado la dimensión subjetiva del recurso de amparo para dotarlo, exclusivamente, de un significado objetivo (...) Para que este Tribunal pueda admitir el recurso de amparo y, en su caso, otorgar la tutela del derecho fundamental que se estima vulnerado, ya no basta que se haya producido la lesión subjetiva del derecho fundamental, sino que la admisión y tutela sólo procederá si a esa lesión subjetiva se une el indispensable requisito objetivo de que el recurso posea una "especial trascendencia constitucional" [art. 50.1 b) LOTC]» $\rangle^{18}$.

En este auto el Tribunal reconoce la objetivación del recurso de amparo por lo que no cabe invocar exclusivamente la lesión del derecho fundamental $^{19}$. Por el contrario, en esta resolución se afirma expresamente que el supuesto de «grave perjuicio para los titulares de los derechos fundamentales que se denuncian como lesionados», fue descartado durante la tramitación parlamentaria del proyecto de reforma de la LOTC 6/2007, al rechazarse

16 Pérez Guerra, R., «El nuevo amparo constitucional: la STC 155/2009, de 25 de junio y su fundamentación jurídica», La Ley: Revista jurídica española de doctrina, jurisprudencia y bibliografia, núm. 7748, 2011, pp. 9-14..

17 Véase Aragón Reyes, M., «Cuestionario sobre la Reforma de la Ley Orgánica del Tribunal Constitucional», ob. cit., p.7; CARRILlo, M., «La objetivación del recurso de amparo: una necesidad ineludible», Revista Vasca de Administración Pública, núm. 81, 2008, p. 87; LóPez Pietsch, P., «Objetivar el recurso de amparo: las recomendaciones de la Comisión Benda y el Debate Español», Revista Española de Derecho Constitucional, Año 18, núm. 53, mayo-agosto 1998, p. 137, entre otros.

18 Véase el ATC 29/2011, de 17 de marzo.

${ }_{19}$ Al respecto en la STC 140/2013, de 8 de julio, FJ 4º afirmó que «la demanda de amparo ha de contener dos líneas argumentativas nítidamente diferenciadas: la relativa a la lesión del derecho fundamental cuyo amparo se pretende, y la atinente a la trascendencia constitucional del recurso tendente a su preservación y establecimiento. Ambas son indispensables, de tal forma que la exposición acerca de la apariencia de la vulneración no puede suplir la carencia de un razonamiento explícito sobre la trascendencia constitucional del recurso de amparo». En el mismo sentido, la STC 69/2011, de 16 de mayo, FJ $3^{\circ}$, impone al recurrente «un esfuerzo argumental que ponga en conexión las vulneraciones constitucionales que alega con los criterios establecidos en el art. 50.1 b) LOTC, precepto este último, según el cual, la especial trascendencia del recurso se apreciará atendiendo a su importancia para la interpretación de la Constitución, para su aplicación o para su general eficacia, y para la determinación del contenido y alcance de los derechos fundamentales». 
la enmienda que proponía la dimensión subjetiva del recurso. Consecuentemente, no queda más que justificar satisfactoriamente la especial trascendencia constitucional para que el amparo sea procedente.

\subsection{La imposición al demandante de justificar la relevancia constitu- cional}

La exigencia procesal para la admisión del amparo art. 49.1 LOTC a la letra dice:

"El recurso de amparo constitucional se iniciará mediante demanda en la que se expondrá con claridad y concisión los hechos que la fundamenten, se citarán los preceptos constitucionales que se estimen infringidos y se fijará con precisión el amparo que se solicita para preservar o establecer el derecho o la libertad que se considere vulnerado. En todo caso, la demanda justificará la especial trascendencia constitucional del recurso».

La modificación del recurso de amparo involucra ciertas expectativas procesales que consisten en imponer al recurrente la carga de justificar la especial trascendencia constitucional, cuyo incumplimiento provocaría inmediatamente la inadmisión sin posibilidad de subsanación ${ }^{20}$. Para este apartado hemos divido la fase de trámite de admisión del recurso de amparo en: a) la verificación del juicio de admisión a trámite, que no es otra cosa que la concurrencia de motivos de admisión, y b) la resolución de inadmisión, que es la providencia que dicta la sección y que no requiere ser motivada.

\subsubsection{Verificación del juicio de admisión a trámite}

En relación a la obligación del recurrente para satisfacer necesariamente el juicio de relevancia constitucional para la admisión a trámite del amparo, Montañés Pardo ha dicho, que se «ha invertido el juicio de admisibilidad, ya que se ha pasado de comprobar la inexistencia de causa de inadmisión a examinar la concurrencia de motivos de admisión $\rangle^{21}$. Ello implica una carga procesal extraordinaria y agravada para el solicitante, dado que no basta con justificar la transgresión del derecho sino que se requiere acreditar la relevancia constitucional del asunto, sopesando, a nuestro parecer, la forma (presupuesto procesal de admisión) antes que el fondo (la violación del derecho sustantivo).

Se ha endurecido tanto el recurso de amparo que la reforma impide corregir el requisito de la especial trascendencia constitucional (arts. $49.1 \mathrm{y}$ 50.1 de la LOTC), por lo que no es posible la apertura del trámite para subsanar ni existe mecanismo legal para recurrir la providencia que decreta la

${ }^{20}$ Ver las SSTC 155/2009, de 25 de junio, FJ 2º 68/2011, de 16 de mayo, FJ $3^{\circ}$, entre otras.

${ }^{21}$ Montañés Pardo, M. A., «La "especial trascendencia constitucional" como presupuesto del recurso de amparo», Foro de Opinión, Otrosí, núm. 1, 2010, p. 30. 
inadmisión por falta de trascendencia constitucional ${ }^{22}$. De hecho, contra la providencia de inadmisión sólo cabe el recurso de súplica que puede interponer únicamente el Ministerio Fiscal (art. 50.3 LOTC), dejando en estado de indefensión al «promovente» ${ }^{23}$.

El trámite de admisión del recurso de amparo desde el inicio suscitó diversas dudas por la imprecisión de los supuestos de admisión y por la deficiente información sobre cómo debía cumplirse dicha carga procesal, provocando confusión y desconcierto ${ }^{24}$. En este sentido, el que fuera Magistrado Eugenio Gay Montalvo en un voto particular destacó la ambigüedad del requisito de la especial trascendencia constitucional y la necesidad de aclararlo, señalando;

«(...) ha de admitirse como posible un justificación de la especial trascendencia constitucional que derive de un modo indudable de la relación fáctica y de la argumentación jurídica hecha por el recurrente (...) dado que la LOTC 6/2007 no incorpora un periodo de vacatio legis, considero que el Tribunal, en asunción de su función de protección de los derechos fundamentales, no podía menos que mostrar una mayor flexibilidad, durante, al menos los primeros meses de aplicación de la Ley (...) evitando que el requisito se convierta en un formalismo enervante (...) $\rangle^{25}$.

$\mathrm{El}$ argumento citado pugna por la tutela constitucional de los derechos y libertades cuando las vías ordinarias de protección han resultado insatisfactorias, lo que pareciera indicar que discrepa de la interpretación objetiva de la admisión del recurso de amparo que legó la reforma. Lamentablemente la propuesta del antiguo Magistrado Eugenio Gay Montalvo no tuvo el apoyo necesario para erigirse como única interpretación posible. Por el contrario, el nuevo criterio adoptado exigió que la demanda de amparo justificará a cabalidad la relevancia constitucional de conformidad con lo establecido en el art. 50.1, letra b), LOTC 6/2007, por lo que aún y cuando la afectación del derecho fundamental (art. 53.2 CE) sea visible, la demanda de amparo no podría ser admitida.

22 Fernández Segado, F., La reforma del régimen jurídico-procesal del recurso de amparo, Dykinson, Madrid, 2007, p. 94.

${ }_{23}$ Al respecto cabría preguntarse si dicha providencia de inadmisión podría ser llevada al Tribunal Europeo de Derechos Humanos bajo el argumento de vulneración del derecho a la tutela judicial efectiva en su vertiente de acceso a la justicia constitucional y del derecho a un proceso con todas las garantías en su vertiente, de falta de motivación, en la resolución.

${ }^{24}$ Diversos autores han señalado posibles sanciones a España por esta regulación. García Roca, J., «La cifra del amparo constitucional y su reforma», en Pérez Tremps, P. (Coord.), La reforma del recurso de amparo, Tirant lo Blanch, Valencia, 2004, p. 286; MAtia Portilla, F. J., «La especial trascendencia constitucional y la inadmisión del recurso de amparo», Revista Española de Derecho Constitucional, núm. 86, mayo-agosto 2009, p. 361, entre otros.

${ }^{25}$ ATC 289/2008, de 22 de septiembre, FJ $2^{\circ}$. 


\subsubsection{Resolución de inadmisión}

Antes de la entrada en vigor de la reforma LOTC 6/2007, de 24 de mayo, el Tribunal motivaba su decisión de inadmisión de amparo aunque fuera de manera breve, señalando cuál o cuáles eran las causas aplicadas. Ahora se exige que la decisión que inadmite a trámite el amparo sea a través de providencia sin que se precise argumento alguno sobre la resolución ${ }^{26}$. En otras palabras, el examen del trámite de admisión verifica la concurrencia de los requisitos legales exigidos, si no se aprecia dicha concurrencia se emitirá una resolución inmotivada (la providencia), que revela una mera expresión de voluntad sin sustento de ninguna índole.

Cada una de las Salas del Tribunal Constitucional se organiza en dos Secciones formadas por tres Magistrados. Las Secciones tienen la facultad de decidir sobre el trámite de admisión del amparo, sin que los magistrados restantes de la Sala puedan influir en tal decisión. Sin embargo, nada impide que la resolución de inadmisión pueda adoptarse posteriormente en la sentencia pese a su inicial admisión. El Tribunal ha declarado reiteradamente que los defectos insubsanables que pudieran afectar al recurso de amparo no resultan sanados porque haya inicialmente admitido a trámite, de forma que la comprobación de los presupuestos procesales para la viabilidad de la acción pueden reconsiderarse en la sentencia, dando lugar a un pronunciamiento de inadmisión por la falta de tales presupuestos ${ }^{27}$.

En resumen, la ausencia de motivación en las decisiones de inadmisión, además de una posible afectación a la tutela judicial efectiva en su vertiente de resolución motivada, supone denegar tanto a los recurrentes como a los operadores jurídicos, las razones que llevaron a la Sección a inadmitir, por lo que no sería descabellada la idea de recurrir la resolución de inadmisión en instancias internacionales ${ }^{28}$. Sobra decir, que hasta el momento las providencias no son públicas por lo que tampoco existe una referencia sobre aquello que a juicio del Tribunal no tiene especial trascendencia constitucional, que quizás podría servir para delimitar indirectamente su contenido.

${ }^{26}$ Matia Portilla, F. J., «La especial trascendencia constitucional y la inadmisión del recurso de amparo», ob. cit, p. 362. El autor señala en relación a las resoluciones de inadmisión a trámite del recurso de amparo «que la mera indicación del presupuesto procesal incumplido puede bastar en el caso de que dicho incumplimiento sea evidente. Sin embargo, tal parquedad no es de recibo cuando el incumplimiento del mentado requisito ... no es evidente porque cuestiona el derecho del justiciable a comprender los motivos que causen a la inadmisión del amparo solicitado».

${ }_{27}$ SSTC 129/2000, de 16 de mayo, FJ $2^{\circ}$; 18/2002, de 28 de enero, FJ $3^{\circ}$; 158/2002, de 16 de septiembre, $\mathrm{FJ}_{2}{ }^{\circ} ; 89 / 2011$, de 6 de junio, $\mathrm{FJ}_{4}^{\circ}$, entre otras.

${ }_{28}$ VV.AA., «Doctrina del Tribunal Constitucional durante el segundo cuatrimestre de 2007», Revista Española de Derecho Constitucional, núm. 81, septiembre-diciembre 2007, pp. 221-242. 


\section{EL CONCEPTO DE ESPECIAL TRASCENDENCIA CONSTITU- CIONAL}

La modificación del recurso de amparo produjo incertidumbre jurídica en los operadores jurídicos. El legislador no definió el requisito de la relevancia constitucional, tampoco estableció supuestos específicos para su admisión, provocando confusión tanto en el Ministerio Fiscal, abogados, procuradores y solicitantes, como en los propios jueces porque nadie sabía qué asuntos merecían la atención del Tribunal Constitucional.

El desconcierto fue unánime, todos exigían se explicara cuándo y cómo se podía solicitar el recurso de amparo. Fue entonces cuando el Alto Tribunal se vio en la necesidad de dotar de contenido a la especial trascendencia constitucional, otorgándole un tratamiento especial. El requisito de relevancia constitucional es un «concepto jurídico indeterminado». A juicio de autores como Ortega Gutiérrez, la especial trascendencia constitucional puede ser definida como el concepto de indeterminación lógica pero susceptible de ser determinable en la aplicación ${ }^{29}$. Es decir, es posible encontrar una unidad de solución justa al caso, sin suponer la existencia de una única solución. En este proceso el juez deberá determinar un remedio que involucra indefectiblemente la aplicación del margen de apreciación judicial ${ }^{30}$.

Partiendo de este entendido y del comportamiento jurisprudencial, podemos identificar tres posibles criterios de interpretación de la especial trascendencia constitucional: primero, una interpretación positiva consistente en la inclusión de un catálogo de supuestos de admisión que permitan el encuadre jurídico del caso; segundo, una interpretación negativa, en la que por exclusión el Tribunal puede ir determinando el núcleo esencial del requisito, como ocurre con las providencias; y finalmente una interpretación mixta, que es una especie de posición ecléctica que deviene de la resolución de casos difíciles, en los que el Tribunal forzosamente tiene que aplicar su facultad discrecional para decidir sin aparente justificación la única interpretación posible al caso en concreto ${ }^{31}$. No hemos identificado con precisión que el Tribunal se haya decantado por un criterio de interpretación exclusivo sino que ha ido perfilando su doctrina en función del caso ${ }^{32}$.

${ }^{29}$ Ortega Gutiérrez, D., «Especial trascendencia constitucional como concepto jurídico indeterminado. De la reforma de 2007 de la LOTC a la STC 155/2009, de 25 de junio», Teoría y Realidad Constitucional, núm. 25, 2010, p. 497.

30 Véase García de EnTERría, E., «Una nota sobre el interés general como concepto jurídico indeterminado», Revista Española de Derecho Administrativo, núm. 89, 1996, p. 12.

31 Dworkin, R., Los derechos en serio, Ariel, Barcelona, 1984, p.146.

32 Véase SSTC 43/2010, de 26 de julio; 107/2011, de 20 de junio; 153/2012, 16 de julio. Dichas las sentencias no encuadran en ninguno de los supuestos previstos, sin embargo han sido admitidas. A nuestro juicio el interés constitucional de los recursos radica en el incidente de nulidad de actuaciones interpuesto en estos casos. En contraste, la STC 126/2013, de 3 de junio, FJ $2^{\circ}$, destaca porque expresamente reconoce la admisión del 
Fue en marzo del 2009 cuando encontramos el primer esbozo de determinación del concepto de especial trascendencia constitucional, desde que se llevó a cabo la reforma de la LOTC 6/2007 ${ }^{33}$. Tendrían que pasar casi dos años para que el Tribunal Constitucional indicara a través de sentencia qué debemos entender por este decisivo concepto. Sin embargo, sería injusto no mencionar que los primeros pronunciamientos se dieron a través de diversos autos de 2008 y $2009^{34}$. Los autos señalaban algunos lineamientos breves que indicaban la necesidad de acreditar la relevancia constitucional en el fondo del asunto. También se dijo que no se contemplaba la posibilidad de subsanar su defecto, y que el asunto alegado debía servir para la interpretación, aplicación o general eficacia en la determinación del contenido y alcance de los derechos fundamentales.

Finalmente, la concreción de la especial trascendencia constitucional llegó con la STC 155/2009, de 25 de junio, que pretendía aludir a un ámbito limitado de actuación, perfectamente singularizado, aunque su identificación en cada caso continuará siendo imprecisa. La clave para su encuadramiento la encontramos en el fundamento jurídico $2^{\circ}$ que dice en cuáles presupuestos se tiene como acreditada la especial trascendencia constitucional:

"Tales casos serán los siguientes: a) el de un recurso que plantee un problema o una faceta de un derecho fundamental susceptible de amparo sobre el que no haya doctrina del Tribunal Constitucional, supuesto ya enunciado en la STC 70/2009, de 23 de marzo, FJ 1 ; b) o que dé ocasión al Tribunal Constitucional para aclarar o cambiar su doctrina, como consecuencia de un proceso de reflexión interna, como acontece en el caso que ahora nos ocupa, o por el surgimiento de nuevas realidades sociales o de cambios normativos relevantes para la configuración del contenido del derecho fundamental, o de un cambio en la doctrina de los órganos de garantía encargados de la interpretación de los tratados y acuerdos internacionales a los que se refiere el art. $10.2 \mathrm{CE}$; c) o cuando la vulneración del derecho fundamental que se denuncia provenga de la ley o de otra disposición de carácter general; d) o si la vulneración del derecho fundamental traiga causa de una reiterada interpretación jurisprudencial de la ley que el Tribunal Constitucional considere lesiva del derecho fundamental y crea necesario proclamar otra interpretación conforme a la Constitución; e) o bien cuando la doctrina del Tribunal Constitucional sobre el derecho fundamental que se alega en el recurso esté siendo

recurso por plantear una cuestión que permitiría al Tribunal aclarar su doctrina -STC $155 / 2009$, de 25 de junio, FJ $2^{\circ}$, inciso b)- sobre los límites de la eficacia invalidante del incidente de nulidad de actuaciones.

${ }^{33}$ En el mismo sentido véase la STC 70/2009, de 23 de marzo, FJ $1^{\circ}$.

${ }^{34}$ AATC 188/2008, de 21 de julio, FJ $3^{\circ}$; 289/2008, de 22 de septiembre, FJ $2^{\circ}$ y 290/2008, de 22 de septiembre, así como el 80/2009, de 9 de marzo, FFJJ $2^{\circ}$ y $3^{\circ}$. 
incumplida de modo general y reiterado por la jurisdicción ordinaria, o existan resoluciones judiciales contradictorias sobre el derecho fundamental, ya sea interpretando de manera distinta la doctrina constitucional, ya sea aplicándola en unos casos y desconociéndola en otros; f) o en el caso de que un órgano judicial incurra en una negativa manifiesta del deber de acatamiento de la doctrina del Tribunal Constitucional (art. 5 de la Ley Orgánica del Poder Judicial: LOPJ); g) o, en fin, cuando el asunto suscitado, sin estar incluido en ninguno de los supuestos anteriores, trascienda del caso concreto porque plantee una cuestión jurídica de relevante y general repercusión social o económica o tenga unas consecuencias políticas generales, consecuencias que podrían concurrir, sobre todo, aunque no exclusivamente, en determinados amparos electorales o parlamentarios».

En síntesis, efectivamente se aprecia que la especial trascendencia constitucional es un concepto jurídico indeterminado, por ello el Tribunal Constitucional ha establecido siete supuestos (enunciativos no limitativos) en los que es posible admitir a trámite el amparo. La posibilidad de incluir nuevos supuestos deriva del carácter dinámico del Derecho, de cuyo ejercicio no puede descartarse la inclusión de nuevas problemáticas que susciten cuestiones de interés constitucional.

\section{EVOLUCIÓN EN LA DOCTRINA DEL TRIBUNAL CONSTITU- CIONAL}

Parece claro que todos los amparos admitidos entrañan una especial trascendencia constitucional, pero son pocas las sentencias en las que se ha manifestado expresamente cuál supuesto se acredita y por qué razón ${ }^{35}$. No es casual que con frecuencia encontremos algunos amparos sobre los que no está del todo claro cómo se acreditó el requisito del 50.1 LOTC; por lo que sería deseable que se mencionara al menos qué supuesto de relevancia constitucional se justificó, a fin de dilucidar y solidificar el contenido de la doctrina de la especial trascendencia constitucional.

La STC 155/2009, de 25 de junio, FJ $2^{\circ}$, fue una resolución crucial que permitió el encuadre de la relevancia constitucional, que parte de una dicotomía conceptual: a) la lesión de un derecho fundamental o libertad pública que además inexcusablemente requiere que se pruebe la especial trascendencia constitucional; y b) se contempla un lista de casos en los que se puede apreciar la concurrencia de la relevancia constitucional. La sentencia declara nominalmente los supuestos que autorizan la admisión del amparo, sin embargo

${ }^{35}$ Véase por ejemplo las SSTC 54/2010, de 4 de octubre; 66/2010, de 18 de octubre; 97/2012, de 7 de mayo; 153/2012 de 16 de julio, entre otras. En dichas sentencias no se aprecia implícita ni explícitamente la especial trascendencia constitucional. 
es una relación tan abierta que admite un amplio margen de interpretación, de tal suerte que con frecuencia se propicie incertidumbre jurídica al respecto.

\subsection{Ausencia de doctrina constitucional}

Se refiere a los supuestos que planteen cuestiones no resueltas o poco desarrolladas por la jurisprudencia constitucional en relación con los derechos fundamentales y las libertades públicas ${ }^{36}$. El recurso de amparo debe involucrar un problema sobre el que no exista doctrina del Tribunal Constitucional. Se prevén dos categorías posibles relacionadas exclusivamente con el derecho fundamental en juego: a) un problema concreto, o b) una nueva faceta. En otras palabras, la controversia debe enfocarse al examen del conflicto que proponga una inédita manifestación o expresión del derecho, o que incite a la jurisdicción constitucional pronunciarse sobre la proyección de los derechos en determinadas resoluciones judiciales sobre las que no existe aún un criterio resolutivo ${ }^{37}$.

El Tribunal Constitucional conoció de este supuesto en la STC 70/2009, de 23 de marzo, $\mathrm{FJ}^{\circ}{ }^{\circ}$. La sentencia estudió el conflicto que se originó por la aplicación de un acuerdo de la Administración que forzaba a una jubilación por incapacidad permanente de un profesor de secundaria, basada en dos informes médicos sobre su salud psíquica que formaban parte de su historial clínico -derecho a la intimidad-. El caso es relevante porque el Tribunal Constitucional aplica por primera vez el requisito de admisión de la especial trascendencia constitucional por dos cuestiones muy concretas, primero por acreditar que no había doctrina constitucional al respecto y segundo, para brindar seguridad jurídica en la materia ${ }^{38}$.

Otra caso relevante fue el que se presentó con motivo de la STC 58/2010, de 4 de octubre, FJ $3^{\circ}$. La sentencia examinó una problemática de emplazamiento que se dio en un proceso sobre titularidad de la propiedad de un bien inmueble. En el caso la autoridad jurisdiccional declaró desiertos los recursos interpuestos por la abogada del Estado, quien se personó extemporáneamente aduciendo que no había sido emplazada a través del fax que ella misma había proporcionado. La sentencia reconoce la especial trascendencia

${ }^{36}$ Hernández Ramos, M., «La especial trascendencia constitucional del recurso de amparo y su aplicación en la Jurisprudencia del Tribunal Constitucional. Luces y sombras de cuatro años de actividad», Revista Aranzadi Doctrinal, núm. 3, 2011, pp. 101-112.

${ }_{37}$ SSTC 191/2011, de 12 de diciembre, FJ 3; 96/2012, de 7 de mayo, FJ 4º 105/2012, de 11 de mayo, FJ 30; 122/2013, de 20 de mayo, FJ $2^{\circ}$.

${ }^{38}$ En este caso se otorga el amparo por el uso de los informes médicos privados. Los datos sobre la salud física y psíquica es información íntima y especialmente sensible. El órgano administrativo y el judicial deberían haber plasmado tanto la previsión legal que amparaba la afectación de la intimidad del profesor jubilado como el juicio de ponderación entre el derecho fundamental y el interés constitucionalmente protegido y perseguido, del cual se habría evidenciado la idoneidad, necesidad y proporcionalidad de la medida. La sentencia se apoya ampliamente en jurisprudencia europea y constitucional. 
constitucional que deriva de la carencia de pronunciamientos de fondo en la jurisprudencia del Tribunal. Específicamente se abordan las condiciones que en el ámbito de la jurisdicción ordinaria deben reunir los actos de comunicación procesal realizados mediante fax, para que resulten compatibles con el derecho a la tutela judicial efectiva (art. 24.1 CE). Dicha sentencia fue ocasión oportuna para aclarar el sentido y alcance de la doctrina fijada en la STC 268/2005, de 24 de octubre, FJ $3^{\text {o39 }}$.

Finalmente otra resolución destacable fue el ATC 185/2011, de 21 de diciembre, que abordó un caso de pena privativa de libertad que fue sustituida por la expulsión del territorio nacional. En este caso se recurre la resolución que condena a tres años y seis meses de prisión y multa de ochenta euros por causa de delito relacionado con sustancias nocivas para la salud. Posteriormente, mediante auto el juez acordó prorrogar la prisión provisional del acusado hasta la mitad del tiempo de la condena impuesta, el auto fue recurrido en suplica y desestimado. Una vez iniciado el cumplimiento de la pena privativa de libertad el juez acordó la sustitución de la pena de prisión por la expulsión del territorio nacional con prohibición de regresar a España en el plazo de diez años. No obstante, si la expulsión no pudiera llevarse a efecto se cumpliría la pena privativa de la libertad originalmente impuesta, permaneciendo el reo en prisión en tanto se diera cumplimiento a la expulsión. La especial trascendencia constitucional estriba en que se considera necesario aclarar la doctrina sobre la prórroga de la prisión provisional en tanto se ejecuta la expulsión, situación que planta un nuevo problema constitucional ${ }^{40}$.

De acuerdo con Ortega Gutiérrez, el supuesto de ausencia de doctrina introduce un elemento casuístico, vivificador del derecho que obliga necesariamente a un pronunciamiento, debido a la importancia o relevancia de dar respuesta constitucional a una nueva realidad ${ }^{41}$. En consecuencia, nos encontramos ante un supuesto que activa la labor interpretativa del Tribunal Constitucional que debe pronunciarse sobre la afectación de derechos por causa de cambios sociales sobre los cuáles no exista precedente constitucional.

\subsection{Aclaración de doctrina}

El presupuesto también se ocupa de la evolución del derecho por cambios sociales, normativos y pautas establecidas que modifiquen el contenido

39 El Tribunal Constitucional en el fundamento jurídico tercero por primera vez establece las condiciones que en el ámbito de la jurisdicción ordinaria deben de reunir los actos de comunicación procesal realizados mediante fax, supeditando la comunicación a que quede en las actuaciones «constancia fehaciente de la recepción, de su fecha y del contenido de lo comunicado» (art. 152.2 LEC).

${ }^{40}$ El mismo supuesto se justifica en las SSTC 56/2013, 11 de marzo, FJ $1^{\text {o }}$; 79/2013, de 8 de abril, FJ 2o; 115/2013, de 9 de mayo, FJ 20; 147/2013, de 6 de agosto, FJ $2^{\circ}$.

${ }^{41}$ Ortega Gutiérrez, D., «Especial trascendencia constitucional como concepto jurídico indeterminado. De la reforma de 2007 de la LOTC a la STC 155/2009, de 25 de junio», ob. cit., p. 497. 
del derecho fundamental. El proceso obedece a distintos factores: que pueden ser fruto de una reflexión interna del Tribunal para aclarar o cambiar de doctrina, motivados por cambios sociales, o por cambios normativos. El supuesto de una reflexión interna deja un amplio margen de interpretación en manos del juez constitucional, trayendo consigo inevitablemente la ausencia de certeza jurídica. Mientras que la segunda hipótesis es todavía más amplia e imprecisa porque habla de una serie de cambios sociales. Aquí valdría la pena preguntarse ¿qué tipo de cambios? porque todo el tiempo hay cambios sociales que afectan los derechos, por ejemplo: la crisis económica, el desempleo, el terrorismo, todos estos fenómenos sociales pueden alterar significativamente los derechos fundamentales, lo relevante en este caso es establecer cuáles tienen especial interés constitucional. Por último, el supuesto que prevé que el Tribunal Constitucional conocerá de una afectación de derechos que tenga como causa un cambio normativo, puede provocar confusión con el presupuesto de admisión del amparo por vulneración de un derecho fundamental por una ley ${ }^{42}$.

Finalmente, se contempla la posibilidad de admitir el recurso de amparo si se justifica que del cambio de doctrina de algún órgano de garantía encargado de la interpretación de los tratados y acuerdos internacionales ratificados por España, ha afectado la configuración de alguno de los derechos fundamentales. En este apartado, sería prudente especificar qué órganos de garantía, ¿los órganos a los que se refiere el art. 10.2 CE? Si esto fuera así se entendería que son: el Tribunal Europeo de Derechos Humanos, Comité de Derechos Humanos de Naciones Unidas, Tribunal de Justicia de la Unión Europea, así como el propio Tribunal Constitucional. Además resulta al menos cuestionable, prever un supuesto en el que los propios órganos garantes sean quienes lesionen derechos y sobre todo si nos referimos a órganos protectores de derechos fundamentales.

El supuesto que permite la aclaración de la doctrina constitucional, fue actualizado en la STC 17/2011, de 28 de febrero, FJ $2^{\circ}$. En esta ocasión se examinó la vista de un procedimiento abreviado, que tuvo por desistidos a los recurrentes dado que la letrada que concurrió al acto no estaba designada en el poder notarial aportado con la demanda ni se acreditó documentalmente la posibilidad de sustituir a la letrada nombrada desde el inicio. En este sentido, el Tribunal aclaró que bastará con la presencia y aceptación del Procurador que tenía encomendada la representación. La sentencia razona sobre la especial trascendencia constitucional del recurso, que deriva de la carencia de

42 Por ejemplo: las SSTC 162 y 163/2011, ambas de 2 noviembre, FJ $4^{\circ}$, respectivamente. Serie de amparo electorales que impugnan la aplicación de un precepto art. 169.3 de la Ley Orgánica del régimen electoral que fue modificado por la Ley Orgánica 2/2010, que introduce como novedad la exigencia de un porcentaje mínimo de avales para presentar candidaturas a los partidos políticos que no obtuvieron representación parlamentaria en la anterior convocatoria de elecciones generales. Dicho precepto a juicio de los recurrentes vulnera el derecho a acceder a los cargos representativos. 
pronunciamientos del Tribunal que delimitan las consecuencias constitucionales del actual supuesto respecto de otros ya juzgados, dando así ocasión para aclarar el sentido y alcance de la doctrina del derecho a ser asistido por letrado ${ }^{43}$.

Otra resolución interesante fue la STC 36/2011, de 28 de marzo, FJ $2^{\circ}$, que examinó un conflicto laboral en relación con un problema de igualdad ante la ley. El asunto tiene que ver con el doble sistema retributivo de trabajadores adoptado por la empresa British Council, en el que se establecía que según hubieran sido contratados los trabajadores con anterioridad o con posterioridad al año 2004 existiría una variación salarial. La especial trascendencia constitucional del caso deriva de la posibilidad que se ofrece para completar y aclarar la doctrina constitucional relativa al contenido y alcance de derecho a la igualdad en el ámbito de las relaciones laborales, en particular en materia de retribuciones, cuando las diferencias retributivas cuestionadas no tienen su origen en un convenio colectivo, sino en una decisión unilateral del empresario ${ }^{44}$.

Por su parte la STC 61/2011, de 5 de mayo, FJ $2^{\circ}$, conoció de un amparo electoral promovido por la Agrupación Electoral Independiente de Zalduondo que presentó un candidato por la circunscripción de Zalduondo (Ávila) a las elecciones locales convocadas. Al ser proclamado por la junta electoral de zona, fue impugnado por la Abogacía del Estado y por el Ministerio Fiscal, pues consideraba que se trataba de un nuevo intento de continuar desarrollando la vedada actividad política de partidos previamente ilegalizados -Batasuna-. Aunque el candidato recurrente declaró un firme compromiso con las vías pacíficas y democráticas así como una férrea oposición al uso de la violencia para lograr objetivos políticos, el Tribunal Supremo declaró no conforme a derecho la candidatura impugnada, negando la posibilidad de

${ }^{43}$ La sentencia es relevante porque el Tribunal aprovecha para afirmar que el legislador ha querido que la valoración de los magistrados acerca de la especial trascendencia constitucional de cada recurso de amparo venga siempre precedida de su invocación y justificación en el escrito de demanda -art. 49.1 in fine LOTC-, confiriendo así al Tribunal un amplio margen para estimar cuándo el contenido de un recurso de amparo justifica una decisión sobre el fondo. En el mismo sentido, STC 192/2012, de 29 de octubre, FJ $2^{\circ}$.

${ }^{44} \mathrm{Se}$ concluye que la diferencia de trato impugnada no vulnera el art. $14 \mathrm{CE}$, se reitera la doctrina de las SSTC 34/1984, de 9 de marzo, FJ $2^{\circ}$; y 39/2003, de 27 de febrero, FJ 4º, de acuerdo privado a la decisión unilateral del empresario que puede disponer libremente de la retribución del trabajador, respetando los mínimos legales o convencionales: en la medida en que estas diferencias salariales no tengan un significado discriminatorio, no pueden considerarse vulneradoras del principio de igualdad. La doble escala salarial enjuiciada resulta constitucional, al no haber sido establecida por ley o convenio colectivo, sino por decisión unilateral del empresario, y dado que una diferencia salarial tasada en la fecha de contratación no puede considerase incluida en ninguna de las causas de discriminación prohibida por la Constitución o por la ley. A mayor abundamiento véase la STC 27/2004, de 4 de marzo, FJ $5^{\circ}$. 
concurrir a elecciones ${ }^{45}$. En esta sentencia cabe apreciar la especial trascendencia constitucional del recurso dado que propicia analizar la determinación del contenido y alcance de los derechos de participación política y sufragio pasivo. Adicionalmente se expresa que debe ser el Pleno del Tribunal Constitucional quien resuelva el recurso de amparo electoral por la importancia que plantea en la interpretación de los derechos fundamentales afectados, por lo que en este caso, a juicio del Tribunal, fue posible considerar satisfecha la exigencia de relevancia constitucional.

Otro ejemplo fue el suscitado en la STC 68/2011, de 16 de mayo, FJ $3^{\circ}$, un juzgado de lo penal con motivo del incumplimiento de la sanción derivado de un delito de propiedad intelectual, impuso una pena de prisión que fue sustituida por la expulsión del territorio nacional. El recurrente solicitó amparo por considerar vulnerados sus derechos a la libertad personal y a la tutela judicial efectiva (resolución inmotivada) ${ }^{46}$. La especial trascendencia constitucional del recurso plantea un problema sobre una faceta de un derecho a la tutela judicial efectiva por la interpretación de la suspensión de la condena de manera no favorable al recurrente y posteriormente en relación con el derecho a la libertad, sobre la que no existe una doctrina claramente delimitada, considerando el Tribunal esta ocasión oportuna para aclararla o cambiarla ${ }^{47}$.

\subsection{Vulneración de derechos fundamentales en la ley}

El supuesto prevé la hipótesis de una posible vulneración del derecho fundamental por la ley o por otra disposición de carácter general. Al respecto se incluye dos posibilidades: la primera, relativa a la disposición general que se utiliza como base del acto impugnado y del que resulta la inconstitucionalidad por vulnerar un derecho fundamental; y segunda, el supuesto que se

${ }^{45}$ Se resuelve otorgar el amparo por la vulneración del derecho a la participación política. El Tribunal Constitucional concluye que la exclusiva referencia que hace el Tribunal Supremo -apreciación subjetiva- de la posible conexión de la Agrupación Electoral Independiente de Zalduondo con ETA y la consecuente aplicación de inhabilitación para concurrir a las elecciones, vulnera directamente el derecho fundamental al sufragio pasivo.

${ }^{46}$ Se otorga el amparo por vulneración del derecho a la tutela judicial efectiva sin indefensión, pues al llevarse a cabo el procedimiento en un órgano unipersonal, los recurrentes podían conferir su representación sólo al Procurador o bien al propio abogado y, al ser conferida al primero, sólo a él le era exigible acreditar documentalmente el mandato. Por lo que resulta irrelevante que la letrada compareciera sin acreditar la sustitución mencionada y sin poder notarial. Se anulan los autos recaídos y se retrotraen las actuaciones a fin de que se celebre nuevamente la vista del procedimiento abreviado.

${ }^{47}$ En este caso cabe hacer la aclaración que no debe de confundirse la fundamentación de la lesión constitucional con la carga de justificar la especial trascendencia constitucional. No corresponde al Tribunal Constitucional reconstruir de oficio la demanda cuando el recurrente incumpla la carga de la argumentación que sobre él recae, en orden a justificar la especial trascendencia constitucional de su recurso. 
refiere a la declaración de inconstitucionalidad de una norma general y un órgano judicial que a posteriori resuelva la controversia con arreglo a la norma ya jurídicamente inexistente por desconocerlo.

Un ejemplo fue el que se presentó en el STC 165/2011, de 12 de noviembre, $\mathrm{FJ} 2^{\circ}$. La sentencia razona la problemática de Unificación Comunista de España, partido político que presentó una candidatura en Navarra que no fue proclamada porque no contaba con los avales suficientes, negándosele la posibilidad de subsanar el defecto precedido. La especial trascendencia constitucional deriva de la vulneración aducida del derecho a acceder en condiciones de igualdad a las funciones y cargos públicos con los requisitos que señalen las leyes ${ }^{48}$. En este caso el Tribunal otorga el amparo, declarando la nulidad del acuerdo que impide subsanar la omisión en la presentación de avales ya declarada en las SSTC 162/2011 y 163/2011, ambas de 2 de noviembre.

Otra sentencia fue la STC 116/2013, de 20 de mayo, FJ $3^{\circ}$. Aquí un trabajador a tiempo parcial acude a solicitar su pensión de jubilación, misma que le fue denegada por no reunir el período mínimo de cotización de quince años. El trabajador aduce vulneración del derecho a la igualdad en la ley, en la medida que el cómputo del período de cotización para el acceso a la pensión de jubilación que contempla la Ley general de la Seguridad Social, discrimina a los trabajadores a tiempo parcial respecto de los trabajadores a tiempo completo. En esta resolución, el Tribunal decide admitir a trámite el recurso de amparo, por entender que la especial trascendencia constitucional del caso se subsume en el supuesto que contempla la admisión del recurso cuando la vulneración del derecho fundamental que se denuncia proviene de la ley ${ }^{49}$.

Una situación poco frecuente fue lo ocurrido en la STC 163/2011, de 2 de noviembre, $\mathrm{FJ} 4^{\circ}$. El recurso cuestionó la constitucionalidad del artículo 169.3 de la Ley Orgánica del Régimen Electoral General, precepto que exigía la presentación de avales para las candidaturas, cuya aplicación afirmó el

48 Se otorga el amparo electoral, al considerase vulnerado el derecho al acceso a la justicia, porque el juzgado impidió la interposición del recurso alegando ineficacia del poder conferido al representante general en el ámbito contencioso electoral, incurriendo en una interpretación en exceso rigorista y no acorde con el contenido de acceso a la justicia el cual incorpora un principio pro actione, aquí ignorado. En este sentido, el Tribunal reconoce que por la sola aceptación de la candidatura, se otorga un apoderamiento general válido para actuar en todos los procedimientos judiciales electorales. Asimismo, reitera la doctrina sobre la subsanabilidad de la insuficiencia de avales para presentar las candidaturas.

49 El Tribunal otorga el amparo y reitera la doctrina de la STC 61/2013, de 14 de marzo, FJ $6^{\circ}$, que declara inconstitucional y nulo el precepto que establece que para determinar los períodos de cotización de jubilación e incapacidad permanente, se computarán exclusivamente las cotizaciones efectuadas en función de las horas trabajadas. En el mismo sentido véase las SSTC 71/2013 y 72/2013, ambas de 8 de abril, FJ $4^{\circ}$ y FJ $2^{\circ}$ respectivamente. 
Tribunal Constitucional, vulneró el derecho de acceso a los cargos públicos de los candidatos. Son contadas las ocasiones en las que el Alto Tribunal ha admitido el recurso de amparo por vulneración de un derecho fundamental por la ley. Por el contrario, lo que normalmente suele ocurrir es que el juez disipe sus dudas constitucionales previamente a través de la cuestión interna de inconstitucionalidad y posteriormente vía amparo dicte sentencia en relación a la afectación del derecho fundamental.

\subsection{Vulneración del derecho fundamental en la aplicación de la ley}

El supuesto lo que pretende es revisar la interpretación jurisprudencial de la ley en los casos sobre los que no haya jurisprudencia, o en los temas que se consideren insuficientes o deficientes en la tutela de los derechos fundamentales. El presupuesto excluye aquellas interpretaciones reiteradas y contrarias a la Constitución que realicen los órganos jurisdiccionales, verificando que la lesión del derecho fundamental surja de una errónea interpretación constitucional de la que el Tribunal Constitucional crea necesario proclamar otra interpretación.

Un ejemplo fue el que se presentó en el ATC 165/2011, de 12 de diciembre. El auto resuelve el recurso de súplica interpuesto, con motivo de una problemática sobre intervención judicial de las comunicaciones de un recluso en el que se aduce vulneración del derecho al secreto de las comunicaciones. Al respecto el Tribunal Constitucional decide admitir a trámite el recurso de amparo, ya que entiende que la especial trascendencia constitucional procede del incumplimiento jurisdiccional de la doctrina constitucional sobre secreto de las comunicaciones de los internos en centros penitenciarios ${ }^{50}$. En este sentido, se propone la posibilidad de que el Tribunal emita un nuevo pronunciamiento sobre éste derecho cuando se trate de la comunicación entre interno y la autoridad judicial que verse sobre quejas de malos tratos.

\subsection{Incumplimiento jurisdiccional reiterado de la doctrina constitucional}

El supuesto se centra en el incumplimiento de la doctrina del Tribunal Constitucional sobre algún derecho fundamental. La alegación debe plasmarse en el recurso justificando que la doctrina ha sido incumplida de modo general y reiterado por la jurisdicción ordinaria, o existan resoluciones judiciales contradictorias sobre el derecho fundamental, ya sea interpretado de manera distinta la doctrina constitucional, ya sea aplicándola en unos casos y desconociéndola en otros.

En este presupuesto se distingue el incumplimiento general por varios órganos judiciales del incumplimiento reiterado (por el mismo órgano judicial) de la jurisprudencia constitucional. Páez Mañá advierte que el

${ }^{50}$ En el mismo sentido, véase las SSTC 175/2000, de 26 de junio, FJ 2º $; 15 / 2011$, de 28 de febrero, $\mathrm{FJ}^{\circ}$. 
supuesto entraña un error de argumentación jurídica, al utilizar una incorrecta expresión que hace referencia al incumplimiento «general y reiterado», porque establece un doble requisito que formula una redundancia ya que, si el incumplimiento es general, la reiteración ha de venir indefectiblemente en la resolución de los asuntos planteados ante los órganos jurisdiccionales ${ }^{51}$.

Es hasta cierto punto sorprendente para un Estado de Derecho que el supuesto se base en que alguno de sus integrantes (Poder judicial), no respeten el artículo 1.1 de la LOTC. Afirmación compartida por Ortega Gutiérrez, quien sostiene que al ser el Tribunal Constitucional el supremo intérprete de la Constitución, lo lógico sería que el poder judicial atienda y respete la LOTC y la Ley Orgánica 6/1985, de 1 de julio, del Poder Judicial, que indican que los jueces y tribunales interpretarán y aplicarán las leyes y reglamentos según los preceptos y principios constitucionales, conforme a la doctrina del Tribunal Constitucional ${ }^{52}$.

El supuesto de desobediencia judicial no se acota con su nominación, sino que además se prevé que sea reiterada. No podemos afirmar si reiterada sean dos, tres, o diez veces, por lo que será el propio juez constitucional quien tendrá que especificarlo.

Junto a este caso se incluye también las interpretaciones contradictorias sobre un derecho. El supuesto equipara la existencia de resoluciones judiciales contradictorias al incumplimiento de la doctrina constitucional, por lo que se entiende que el Tribunal Constitucional deberá determinar, y en eso consistirá la especial trascendencia constitucional, cuál es la correcta interpretación conforme a la Constitución de dos o más interpretaciones que estén en contradicción. Empero no resulta del todo claro que la inaplicación se considere como una parte de la contradicción, como parece deducirse de la redacción de este supuesto, salvo que «desconocer» signifique que sea contradictorio, pero esta suposición es difícilmente asumible.

En cualquier caso, lo cierto es que hasta el momento no hemos identificado alguna resolución que haya sido admitida por acreditar este supuesto de forma explícita.

\subsection{Negativa judicial de acatamiento de la doctrina constitucional}

El supuesto vincula a todos los jueces y tribunales (intérpretes y aplicadores de las leyes y reglamentos) para que emitan sus resoluciones de con-

${ }^{51}$ PÁez Mañá, J.,«El requisito de la especial trascendencia constitucional en los recursos de amparo interpuestos ante el Tribunal Constitucional español», en BAUZÁ REILlY M., y Bueno Mata F., (Coords.), El Derecho en la sociedad telemática. Estudios en homenaje al profesor Valentín Carrascosa López, Andavira Editora, Santiago de Compostela, 2012, pp. 511-541.

52 Ortega Gutiérrez, D., «Especial trascendencia constitucional como concepto jurídico indeterminado. De la reforma de 2007 de la LOTC a la STC 155/2009, de 25 de junio», ob. cit., p. 509. 
formidad con la doctrina sentada por el Tribunal Constitucional. Basta que un solo órgano se aparte de la doctrina constitucional para aplicar este precepto, con ello se pretende corregir vía amparo los casos de manifiesta «rebeldía judicial».

En relación a este supuesto, el Tribunal ha tenido ocasión de pronunciarse en varias ocasiones. Primero, en la STC 59/2011, de 3 de mayo, FJ $8^{\circ}$, la sentencia analiza las respuestas que emite un juez sobre la valoración de una falta grave cometida por un interno en centro penitenciario ${ }^{53}$. En este caso el Tribunal Constitucional hace notar que el órgano judicial incurrió en negativa manifiesta del deber de acatamiento de la doctrina constitucional, pues insistió en dar respuesta estereotipada en varias ocasiones al recurrente, pese a que desde la STC 268/2006, de 11 de septiembre, FJ $9^{\circ}$, se ha reiterado que dicha contestación vulnera el derecho a la tutela judicial efectiva. Esta circunstancia no sólo pone de manifiesto la relevancia constitucional del recurso de amparo, sino que, además, sirvió de justificación para que el Tribunal Constitucional exhortara al órgano judicial a obedecer la doctrina constitucional sobre el particular ${ }^{54}$.

En la misma línea argumentativa destacamos la STC 133/2011, de 18 de julio, FJ $3^{\circ}$, que conoce sobre una condena por delito fiscal cometido en el año de 1998 y que fue denunciado en el año 2004. La especial trascendencia constitucional del caso deriva de que aun siendo conocedores de la existencia de una decisión clara del Tribunal Constitucional sobre cómputo de plazo de prescripción, deciden los órganos judiciales conscientemente no aplicar dicha doctrina ${ }^{55}$.

Finalmente, una de las ultimas resoluciones del Tribunal Constitucional que merece ser mencionado es el ATC 26/2012, de 31 de enero, porque a pesar de que desestima el recurso de súplica para la admisión del amparo,

${ }^{53}$ La sentencia concede el amparo reiterando la doctrina que establece que en los procedimientos disciplinarios incoados a los internos en centros penitenciarios deben extremarse las garantías procedimentales del artículo $24 \mathrm{CE}$. El Tribunal Constitucional hace notar que el órgano judicial ha incurrido en una negativa manifiesta del deber de acatamiento de la doctrina constitucional, pues ha insistido en dar respuesta estereotipada -en ocho ocasiones- a las alegaciones aducidas, pese a que desde la STC 268/2006, de 11 de septiembre, $\mathrm{FJ}^{\circ}$, se le ha reiterado que dicha contestación vulnera el derecho a la tutela judicial efectiva.

${ }_{54}$ VV.AA., «Doctrina del Tribunal Constitucional durante el tercer cuatrimestre de 2009», Revista Española de Derecho Constitucional, núm. 88, enero-abril 2010, pp. 311330.

${ }^{55}$ Las sentencias anuladas ponen de relieve que los órganos judiciales conocían la existencia de una reiterada jurisprudencia constitucional (que arranca con la STC 63/2005, de 14 de marzo, $\mathrm{FJ}^{\circ}$ ) respecto de la interpretación del régimen de prescripción de delitos regulado en el artículo 132.2 del Código Penal, vigente en el momento de la condena. A pesar de ello, decidieron no aplicar esa doctrina, lo que implica una contravención de su obligación de aplicar las normas conforme a la interpretación que de ellas haya realizado el Tribunal Constitucional. Consecuentemente, dichas resoluciones vulneran el derecho a la tutela judicial efectiva de los demandantes de amparo. 
el Tribunal aprovecha este auto para abundar sobre la doctrina del supuesto f) de la STC 155/2009, de 25 de junio, FJ $2^{\circ}$. Afirmando que la errónea interpretación o aplicación de la jurisprudencia, incluso si fuera objetivable y verificable en el caso concreto, es algo radicalmente distinto a la voluntad manifiesta de no proceder a su aplicación; dicho en otras palabras, algo diferente a la decisión consciente de soslayarla elemento intencional o volitivo que caracteriza el concreto supuesto de la especial trascendencia constitucional $^{56}$.

La actuación resistente de los órganos judiciales no se razona en el recurso formulado ni se advierte en las resoluciones judiciales recurridas en amparo, que acertadas o no en su operación aplicativa de la doctrina del Tribunal Constitucional, parten expresamente de la jurisprudencia constitucional, que detalladamente reproducen, y la extiende a la resolución del litigio. En consecuencia, tanto por la falta de cumplimiento de la carga de justificación, como por la ausencia de evidencia alguna que revela esa intención de incumplimiento de la doctrina constitucional se confirma la inadmisión del recurso de amparo.

En suma, no es nada tranquilizador que un órgano judicial no respete el ordenamiento jurídico y la función constitucional del denominado «poder corrector». Los argumentos son los mismos que para el supuesto e) -incumplimiento jurisdiccional reiterado de la doctrina constitucional-, la diferencia estriba en el presupuesto de desobediencia manifiesta de un órgano judicial, es decir, el juez debe conocer la doctrina que tendría que seguir y aun así decidir no acatarla. De facto, a nuestro juicio, se intenta establecer una especie de vinculación jurisprudencial ${ }^{57}$ de las sentencias del Tribunal Constitucional, que pareciera responder a las discrepancias doctrinarles que a veces se llegan a tener con el Tribunal Supremo.

\subsection{Repercusión social, económica o política}

El supuesto prevé distintas hipótesis procesales, cuatro enunciativas y una cláusula abierta, entre las que podemos identificar: primero, cuando el supuesto trascienda del caso concreto porque plantea una cuestión jurídica relevante; segundo, cuando el asunto tenga general repercusión social; ter-

${ }^{56}$ Otras resoluciones que abundan en el supuesto f) de la STC 155/2009, de 25 de junio, FJ $2^{\circ}$, son las SSTC 1 y 2/2013, ambas de 14 de enero, FJ $3^{\circ}$ en las dos; 32/2013, de 11 de febrero, FJ $2^{\circ}$.

${ }^{57}$ Como con acierto observa CABAÑAs García, J. C., «El recurso de amparo que queremos (reflexiones a propósito de la Ley Orgánica 6/2007, de 24 de mayo, de reforma parcial de la Ley Orgánica del Tribunal Constitucional)», Revista Española de Derecho Constitucional, núm. 88, enero-abril 2010, p. 68: «Si se descuida este flanco del mantenimiento y las conservación de la jurisprudencia ya creada, el peligro de que los tribunales ordinarios tiendan a sentirse menos vinculados por la jurisprudencia no resulta para nada descabellado, teniendo en cuenta que las decisiones que aquéllos dicten no serán objeto de control hasta que no alcance el grado de la reiteración». 
cero, cuando el conflicto que se plantea tenga general repercusión económica; y cuarto, cuando el objeto de análisis apela a consecuencias políticas generales (que pueden concurrir en determinados amparos electorales o parlamentarios).

«General» es quizás la palabra más utilizada en este presupuesto y también la menos clara. Lo general, lo público o común alude a un concepto indeterminado, de ahí que nos encontremos ante el típico supuesto de «cajón de sastre», cuya interpretación puede funcionar y funciona, para incluir o excluir ciertas actuaciones. El Tribunal Constitucional tendrá que decidir en cada caso, qué entiende por cuestión jurídica relevante y general repercusión social o económica. En consecuencia, tendremos que ajustarnos a las apreciaciones (temporales y especiales) del juez constitucional que deberá inexcusablemente interpretar el alcance del significado jurídico en los casos cuestionados.

Al respecto García de Enterría ha afirmado que es más que evidente que el Tribunal Constitucional está dotado de interés público para deliberar sobre el tratamiento de un concepto jurídico indeterminado donde puede aplicar la técnica del margen de apreciación, que a su juicio, es la base sobre la que se justifica la legitimidad del enjuiciamiento judicial ${ }^{58}$. En nuestro caso dicha apreciación tendrá que encuadrarse primero en el supuesto g) previsto para posteriormente, desentrañar la hipótesis (social, económica o política) que permite la admisibilidad del caso.

El Tribunal en pocas sentencias se ha pronunciado con claridad sobre la procedencia del recurso de amparo derivado de la repercusión política del asunto, a pesar del importante número de amparos electorales que se han dictado. Una primera sentencia que contempló el supuesto, aunque no de manera exclusiva fue la STC 60/2011, de 5 de mayo, FJ $2^{\circ}$, que conoció de un amparo electoral interpuesto por un partido político al que se le denegó la proclamación de algunas candidaturas en elecciones municipales ${ }^{59}$. La especial trascendencia constitucional se acreditó por dos supuestos de procedencia: a) por tener repercusión política y ser importante para la aplicación de la Constitución en el régimen de participación ciudadana en el sistema democrático, mediante la elección de los representantes públicos; y b) por contribuir a perfilar el contenido y alcance de los derechos a participar en condiciones de igualdad en los asuntos públicos.

${ }^{58}$ García de Enterría, E., «Una nota sobre el interés general como concepto jurídico indeterminado», ob. cit., p. 8.

${ }^{59}$ El Tribunal otorga el amparo porque consideró que se vulneró el derecho a la tutela judicial efectiva de la coalición, en su vertiente de acceso al proceso debido a que el emplazamiento se llevó a cabo por conducto de la Junta Electoral de zona y no de forma personal. Dicha situación produjo indefensión al recurrente, y, en la de falta de motivación suficiente, puesto que la cognitio judicial aparece limitada y condicionada como consecuencia de esa indefensión. También vulneró el derecho de sufragio pasivo de la coalición electoral, así como el derecho al sufragio activo de los electores. 
Otra sentencia es la STC 141/2012, de 2 de julio de 2012, FJ $2^{\circ}$, que analiza la problemática que recae sobre la ratificación del mantenimiento de un internamiento de un paciente en un hospital psiquiátrico, cuya alta médica se había otorgado, lo que presupone privación ilegal de la libertad. En el transcurso del proceso el paciente solicita el desistimiento de recurso, mismo que fue rechazado. El Tribunal concede el amparo al verificar que el mantenimiento del internamiento incurrió en excesos provocando privación ilegal de la libertad del paciente. El Alto Tribunal aprecia que la especial trascendencia constitucional deriva del rechazo del desistimiento solicitado por el recurrente, por entender el Tribunal Constitucional que el recurso de amparo plantea una problemática que trasciende al individuo, al abordarse cuestiones de interés público ${ }^{60}$.

Sobre la repercusión socioeconómica del asunto nos apoyaremos en dos resoluciones: la STC $183 / 2011$, de 21 de noviembre, FFJJ $1^{\circ}$ y $2^{\circ}$, y el ATC 29/2011, de 14 de marzo. La sentencia conoce de un amparo que promueve el Consejo General de Colegios Oficiales de Aparejadores y Arquitectos Técnicos quienes impugnaron el acuerdo del Consejo de Ministros, por introducir el título universitario «graduado o graduada en ingeniería de edificación», título que habilita al ejercicio de la profesión de arquitecto técnico. El Tribunal Supremo anuló el acuerdo al considerar que la denominación induce a confusión, al entender que los arquitectos técnicos tienen competencia exclusiva en materia de edificación, en detrimento de otras profesiones. En este caso se justifica la especial trascendencia constitucional del inciso g), que deriva de la impugnación de una sentencia con eventual incidencia en el desarrollo del objetivo del espacio europeo de educación superior, que consiste en adoptar un sistema de títulos académicos fácilmente comprensibles y comparables en los Estados miembros de la Unión Europea ${ }^{61}$.

El ATC 29/2011, de 17 de marzo, con motivo de un recurso de suplica el Tribunal Constitucional conoció de ciertas alegaciones que exigían se admitiera a trámite el recurso de amparo por concurrir la especial trascendencia constitucional en los casos en que se cause grave perjuicio para los titulares de los derechos fundamentales que se denuncian como lesionados, tal como sucede en el Tribunal Constitucional Federal alemán. Al respecto se arguyó que tras la reforma ya no era suficiente que por sí solo se argumentará una lesión de un derecho fundamental o libertad pública tutelable en amparo, pues es imprescindible, además, acreditar objetivamente la «especial trascendencia constitucional». Sin embargo, es importante advertir que corresponde

${ }^{60}$ Véase también las SSTC 27/2013, de 11 de febrero, FJ $2^{\circ}$; 44/2013, de 25 de febrero, FJ $2^{\circ}$, que actualizan el supuesto del inciso a) y g) de la $155 / 2009$, de 25 de junio, FJ $2^{\circ}$.

${ }^{61}$ La queja basada en que la sentencia impugnada carece de la motivación reforzada que resulta constitucionalmente exigible cuando se halla en juego un derecho sustantivo, en este caso la autonomía universitaria (art. 27.10 CE) es rechazada puesto que se advierte que ni los colegios profesionales, ni las corporaciones profesionales del segundo grado, como la recurrente, son titulares del derecho a la autonomía universitaria. 
al Tribunal Constitucional valorar si el contenido del recurso justifica una decisión sobre el fondo, en razón de su importancia para la interpretación de la Constitución, para su aplicación o su general eficacia y para la determinación del contenido del alcance de los derechos fundamentales. Al respecto el Tribunal ha señalado que:

«Según advertimos en la STC 155/2009, que tal relación no puede ser entendida como un elenco definitivamente cerrado de casos en los que un recurso de amparo tiene especial trascendencia constitucional, pues a tal entendimiento se opone, lógicamente, el carácter dinámico del ejercicio de nuestra jurisdicción, en cuyo desempeño no puede descartarse a partir de la casuística que se presente la necesidad de perfilar o depurar conceptos, redefinir supuestos contemplados, añadir otros nuevos o excluir alguno inicialmente incluido».

Bajo esta lógica, el contenido de la especial trascendencia constitucional no tiene carácter definitivamente cerrado, al contrario, es una manifiesta cláusula abierta, sin que ello signifique que se puedan incluir en tal elenco supuestos que ya han sido excluidos previamente por el legislador, como lo fue el criterio de «grave perjuicio para los titulares de los derechos fundamentales» que fue suprimido en la reforma a la LOTC 6/2007, de 24 de mayo ${ }^{62}$. En consecuencia, se reitera que solo serán admisibles aquellos amparos que justifiquen a cabalidad la relevancia constitucional en los presupuestos contemplados para el efecto.

\section{ALGUNAS CONSIDERACIONES FINALES}

La reforma 6/2007, de 24 de mayo, trasformó abruptamente el recurso de amparo modificándolo en diversos aspectos tanto procedimentales como estructurales. Se introdujo un trámite de admisibilidad especialmente rígido. Asimismo, se disoció al recurso de amparo de la tutela subjetiva de los derechos fundamentales (14 a $29 \mathrm{CE})$ que era su objeto central de protección constitucional. Consecuentemente, la objetivación del amparo se convirtió decididamente en un factor negativo cuando se producía una lesión al derecho fundamental por diversas razones. Por ejemplo: el nuevo recurso limita sustancialmente la irradiación de los derechos fundamentales susceptibles de

62 Solicitado por enmienda número 27 del Grupo Parlamentario Vasco durante la tramitación del proyecto de reforma de la Ley Orgánica 2/1979, del Tribunal Constitucional. La enmienda que no prosperó modificaba el art. 50 proponiendo la adición de un nuevo inciso letra $b$ ) en el que se pedía que «el recurso justificara una decisión sobre el fondo por parte del Tribunal Constitucional bien en razón del perjuicio particularmente grave que se le ocasiona al demandante con la denegación de una decisión sobre el fondo, bien en razón de su especial trascendencia constitucional (...)». Véase Enmiendas e Índices de Enmiendas al Articulado en el Boletín Oficial de las Cortes Generales, Congreso de los Diputados, VIII Legislatura, Serie A, Proyecto de Ley, núm. 60-7, de 23 de febrero de 2006 , pp. 32 y 33 .. 
amparo, menoscabándose la tutela efectiva ante el órgano garante por excelencia y perdiéndose la posible garantía de corregir el error en la jurisdicción constitucional. Hasta el momento la evolución doctrinal indica que de las siete hipótesis jurídicas contempladas en la STC 155/2009, de 25 de junio, solo tres o cuatro han operado, mientras que el resto han sido objeto de breve atención o se está a la espera de su desarrollo.

A la distancia se percibe que el efecto disuasorio de la reforma se ha cumplido insatisfactoriamente, porque aunque efectivamente ha habido una disminución en el número de recursos de amparo que llegan al Tribunal Constitucional, ésta no ha sido verdaderamente significativa. Sin embargo, lo que sí decreció fue el número de sentencias de amparo que se resuelven, fenómeno que responde a la difícil tarea de acreditar indubitablemente el «incomprendido» requisito de la especial trascendencia constitucional $^{63}$. En consecuencia, como es habitual, se continúan incoando un alto número de recursos de amparo, aunque la gran mayoría no superan el trámite de admisibilidad. Es importante destacar que aquellos amparos que no justificaron la especial trascendencia constitucional no necesariamente son recursos irrelevantes o no violatorios de derechos fundamentales. Más aún, a partir del análisis de las sentencias abordadas podemos afirmar que es urgente aclarar y unificar la doctrina constitucional sobre el requisito de la especial trascendencia, cuyos parámetros -hasta el día de hoy-impide entender a plenitud las garantías que tutela el nuevo recurso de amparo.

Otro objetivo en el que, a nuestro juicio, erró la reforma fue aquel que aseguraba que con la objetivación del amparo se aligeraría la carga de trabajo del Tribunal Constitucional propiciando así una justicia constitucional pronta y expedita. El incumplimiento se verifica con el descomunal aumento de las inadmisiones a trámite ${ }^{64}$ por lo que la carga de trabajo del Tribunal no se ha reducido, sólo se ha trasladado a las Secciones.

${ }_{63}$ Sentencias resueltas en amparo: 337 en el año 2006, 231 en el año 2007, 192 en el 2008, 177 en el año 2009, 91 en el año 2010, 145 en el año 2011 y 129 en el año 2012.

${ }^{64} \mathrm{Tal}$ como se desprende de las Memorias del Tribunal Constitucional. Durante el 2006 ingresaron al Tribunal 11,741 asuntos de los cuales 11,471 fueron amparos y de éstos se inadmitieron a trámite 7,441 (95,93\%). En el 2007 entró en vigor la reforma 6/2007, de 24 de mayo, en ese entonces había un retraso considerable en la resolución de amparos por lo que al menos en los primeros tres años (2007 a 2010) el número de inadmisiones superó el número de ingresos. En el 2007 ingresaron 10,013 asuntos, de los cuales 9,840 fueron amparos, y de éstos se inadmitieron a trámite 10,970 (97,69\%). En 2008 ingresaron 10,410 asuntos, 10,279 fueron amparos y de éstos se inadmitieron a trámite 12,474 (98,40\%). Durante el 2009 ingresaron 10,848 asuntos, de los cuales 10,792 fueron amparos y de éstos 13,042 se inadmitieron a trámite (99,63\%). En 2010 ingresaron 9,041 asuntos de los cuales 8,947 fueron amparos y de estos se inadmitieron a trámite 8,984 (98,53\%). En 2011 ingresaron 7,192 asuntos, de éstos 7,098 fueron amparos y se inadmitieron a trámite 5,883 (98,66\%). En 2012 ingresaron 7,294 nuevos asuntos, de éstos 7,205 fueron amparos y se inadmitieron a trámite 7,076 (98,77\%). Como se observa 
En resumen, la pretendida disminución de los recursos y la maximización del control sobre las decisiones de jurisdicción constitucional son dos objetivos en tensión porque mientras uno aparentemente disminuye el otro aumenta. Es decir, a seis años vista, la experiencia nos muestra que el amparo que nos legó la reforma 6/2007, de 24 de mayo, faltó en sus pretendidos objetivos: a) disminuir el número de recursos de amparo y b) permitir un equilibrio entre la carga laboral y la competencia constitucional.

El debate teórico acerca del ámbito de protección del amparo constitucional es harto, complejo y discutible, pero valdría la pena detenerse a reflexionar en los daños colaterales de su reforma. ¿A quién corresponde tutelar los derechos fundamentales?, ¿al poder judicial?, ¿se va introducir un amparo judicial?, ¿cómo ha funcionado el incidente de nulidad de actuaciones tras la reforma?, estas y otras preguntas quedan en el tintero y nos invitan a incursionar en nuevos estudios. Mientras tanto, creemos que es urgente reparar, en el perjuicio que ocasiona el desconocimiento de vulneraciones de derechos fundamentales en la jurisdicción constitucional que propicia la interposición de un interés constitucional aún impreciso. Todo indica que la decisión liminar de admisión a trámite del recurso de amparo se traduce en una facultad discrecional del Tribunal Constitucional a «decidir no decidir tutelar ciertos derechos», trayendo consigo un «recorte» de derechos altamente cuestionable desde el punto de vista constitucional.

RESUMEN: El presente trabajo tiene como finalidad dar cuenta del desarrollo jurisprudencial español del requisito de la especial trascendencia constitucional. En primer lugar, abordaremos los cambios del recurso de amparo a raíz de la reforma de la Ley Orgánica del Tribunal Constitucional 6/2007, de 24 de mayo. En segundo lugar, se analizará el requisito de la especial trascendencia constitucional desde la teoría de concepto juridico indeterminado. Finalmente estudiaremos algunas sentencias y autos que dan contenido a los supuestos de procedencia procesal del amparo constitucional.

PALABRAS CLAVE: recurso de amparo, especial trascendencia constitucional, concepto jurídico indeterminado, reforma, Tribunal Constitucional.

TITLE: The requirement of the special Constitutional significance: «decide not to decide».

ABSTRACT: This paper aims to explain the doctrinal evolution of the special constitutional significance in Spanish Constitutional Court decisions. First, we will study the main impact of the reform of the Organic Law 6/2007, of May 24, on the appeal; secondly we will analyze the concept of this new procedural requirement through constitutional doctrine and,

el número de amparos ingresados no ha disminuido significativamente con la reforma, situación que nos lleva inevitablemente a replantearnos la utilidad de la objetivación del amparo. Información consultada el 22 de agosto del 2013 en www.tribunalconstitucional. es/es/tribunal/memorias/Paginas/default.aspx 
finally, we will study the different resolutions and orders of the Court in order to give content to the special constitutional significance.

KEYWORDS: recurso de amparo (appeal), special constitutional significance (discretionary review), undefined legal concept, reform, Constitutional Court.

Recibido: 24.05.2013

Aceptado: 02.09.2013 